\title{
Crack Healing and Mechanical Properties of Bacteria-based Self-healing Cement Mortar
}

\author{
Reza Zaerkabeh ${ }^{1}$, Alireza Mohammadjafari Sadeghi ${ }^{1 *}$, Hasan Afshin¹, Raheleh Majdani² \\ 1 Faculty of Civil Engineering, Sahand University of Technology, 51335/1996 Tabriz, Iran \\ 2 Faculty of Science, University of Maragheh, 83111 - 55181 Maragheh, Iran \\ * Corresponding author, e-mail: mohammadjafari@sut.ac.ir
}

Received: 19 June 2021, Accepted: 22 February 2021, Published online: 02 March 2022

\begin{abstract}
In this study, the improvement of mechanical properties and crack healing as a result of the calcium carbonate precipitation due to bacterial activity have been investigated in two phases. First, the optimum mix design of self-healing cement mortar has been achieved considering different amounts and concentrations of the bacterial solution of bacterium Sporosarcina pasteurii (ATCC 11859) in non-pre-cracked specimens. Some of the mechanical properties, such as compressive strength, flexural strength, energy absorption capability, and weight change in bacteria added cement mortar specimens are compared with those of control specimens. Second, using the determined optimum mix design, mechanical properties of self-healing cement mortar specimens with initial cracks are compared with those of non-pre-cracked specimens to evaluate the recovery degree. 28-day compressive and flexural strengths of cement mortar specimens through direct addition of bacterial suspension with a concentration of $5.1 \times 10^{7}$ cells $/ \mathrm{ml} \mathrm{improved} \mathrm{by} 45 \%$ and $18 \%$, respectively. These results for 7 -day specimens were $78 \%$ and $24 \%$, respectively. Experimental flexural strengths of pre-cracked specimens are higher than their theoretical values based on the reduced cross-sections, and in pre-cracks with smaller dimensions, higher recovery degrees are achieved.
\end{abstract}

\section{Keywords}

self-healing concrete, cement-based materials, crack healing, microorganism, mechanical properties, flexural strength, biomaterials

\section{Introduction}

Crack propagation is one of the significant factors of damages in concrete structures, which has affected their performance and durability. Therefore, inspection and repairing and maintenance procedures for concrete structures are of great importance. The application of self-healing materials can reduce the need for inspection and maintenance and ultimately leads to saving in costs, workforce, and time [1].

The self-healing approaches available in different healing materials have been studied in both intrinsic and extrinsic groups according to their function and application. The basis of the intrinsic self-healing method is the further hydration of the unreacted cementitious materials, which results in the sealing of cracks. Unhydrated cementitious components and the ability to provide calcium ions are among the factors of intrinsic self-healing potential of cementitious materials. On the other hand, in the extrinsic self-healing process, the use of engineered additives for healing purposes is essential. Polymeric and biological materials and chemical compositions are the most important additives in the extrinsic self-healing method, which are added to the cement matrix by encapsulation, vascular, and immobilization techniques [2-4].

Encapsulation is one of the common approaches for adding a healing agent to the cement matrix, in which microcapsules are incorporated into the concrete mixture during its preparation, and they are expected to be ruptured by the propagation of the cracks and release the healing agent. Different materials have been used for producing capsules containing varied healing agents [5-7]. Microcapsules have also been used in self-healing concrete to encapsulate bacterial spores [8]. The vascular approach is another method of delivering healing agents into self-healing concrete specimens that mimics the vascular structure of the human body. This approach consists of a network of tubes inserted into the concrete and supplied externally by the healing-agent [9]. Immobilization is an approach of embedding microorganisms by various types of materials into an inorganic matrix [4]. Specimens 
incorporated with expanded perlite-immobilized bacteria exhibited crack-healing in widths up to $0.79 \mathrm{~mm}$ after 28 days, which is larger than the value of $0.45 \mathrm{~mm}$ for specimens incorporated with expanded clay-immobilized bacteria [10]. The addition of immobilized Bacillus species by iron oxide nanoparticles to the concrete matrix increased the compressive strength [11].

In the biological method, the bacteria should be capable of withstanding the alkaline environment of the concrete. The addition of ureolytic bacteria, which can produce urease enzymes to catalyze the breakdown of urea to ammonium and carbonate, combined with a calcium source, leads to calcium carbonate precipitation. Calcite precipitation derived from microorganisms causes self-healing in concrete by sealing the micro-cracks and binding aggregates [12]. Lee and Park [13] have investigated approaches to create optimal conditions for the production of calcium carbonate and concluded that production methods should be improved, especially concerning the mass culture of bacteria, nutrients, and labor intensity to satisfy economic constraints. Elevated temperature, nutrient depletion, and high $\mathrm{pH}$ conditions that occur in cement-based materials might prevent microbial-induced calcium carbonate precipitation. Bacterial viability and urea hydrolysis were most affected by exposure to extreme temperature and extreme $\mathrm{pH}$ [14].

Different techniques in terms of carriers and immobilizers have been developed to deliver bacteria into the cementitious matrix before its activation, such as utilizing silica gel, polyurethane, lightweight aggregate, and graphite nanoplatelets [4]. Carriers should have good properties of mechanical and thermal stability, and be biologically inert, and possess suitable matrix porosity for the transmission of particles [15]. Using calcium sulphoaluminate cement as a protective carrier for the bacteria was effective in preserving its activity over a long period. Incorporating this self-healing system in concrete led to sealing the cracks entirely up to $417 \mu \mathrm{m}$ within 28 days, and the compressive strength increased by $130 \%$ compared to the plain mortar [16]. The addition of immobilized bacteria in expanded clay by aggregate replacement in concrete has improved its compressive strength [17]. Bacterial spores were immobilized, and nutrients were encapsulated as two separate components using coated expanded perlite for self-healing concrete [18].

Various types of bacteria can be applied in concrete as healing agents, such as Bacillus sp. CT-5, Bacillus megaterium, Bacillus subtilis, Bacillus aerius, Sporosarcina pasteurii, AKKR5, and Shewanella species. Bacillus sp. CT-5 with the concentration of $5 \times 10^{7}$ cells $/ \mathrm{mm}^{3}$ has healed the cracks of depths up to $27.2 \mathrm{~mm}$ and has increased compressive strength up to $40 \%$ compared to the control specimen, and Sporosarcina pasteurii with the concentration of $10^{5}$ cells $/ \mathrm{ml}$ has raised compressive strength by $35 \%$ [12]. The 28-day split tensile and compressive strengths of specimens containing Bacillus subtilis, Bacillus megaterium, and simultaneous use of both bacteria have increased by $15 \%$. The bacterial concentration is kept at $10^{8}$ cells $/ \mathrm{ml}$. It is determined by finding optical density (OD), which refers to the amount of light scattered while passing through a cell suspension, measured in a spectrophotometer [19]. The bacterial activity of Bacillus subtilis using direct incorporation, and through lightweight aggregates and graphite nanoplatelets carriers in concrete showed that immobilization of bacteria in graphite nanoplatelets in specimens pre-cracked at under 7 days and immobilization of bacteria in lightweight aggregates in specimens pre-cracked at over 7 days were more effective [20]. The results of adding impregnated lightweight aggregates using a chemical solution, biological solution, and also combination of both as healing agents in concrete mixture showed that all self-healing agents were able to seal cracks between 0.08 to $0.22 \mathrm{~mm}$ in width [21]. Abo-El-Enein et al. [22] using alkalophilic aerobic Sporosarcina pasteurii, demonstrated that the 28-day compressive strength of mortar (with the incorporation of about one optical density of bacterial cells) enhanced by $33 \%$. Moreover, the growth of calcite crystals led to improved water absorption. Different calcium sources by mixing with urea and one optical density bacteria cells of $S$. pasteurii were tested to consolidate sand, and the results of calcium chloride medium were more effective compared to other media [23]. By reviewing earlier research, the maximum width, depth, and length of healed cracks were $0.97 \mathrm{~mm}, 32 \mathrm{~mm}$, and $5 \mathrm{~mm}$, respectively [1].

Bacillus pasteurii (Sproscarcins pasteurii), which was used in this study, is a gram-positive bacterium with the ability to survive in highly alkaline conditions $(\mathrm{pH}=10)$. It could be useful in the phenomenon of MICP (Microbiologically Induced Calcite Precipitation) $[24,25]$. In this process, the induction of calcium carbonate precipitation is done with certain microorganisms using appropriate environmental conditions. $B$. pasteurii, as a possible agent in the induction of an important volume of MICP under particular environments, has been noticed recently. This potential of the bacteria refers to its unique ability to produce and secrete copious amounts of the enzyme urease. In the presence of water, the urease enzyme promotes the lysis of urea, a widespread 
biochemical agent with abundant supply. After a generation of negatively charged carbonate ions through some stages, they react with positive metal ions such as calcium, and finally, precipitation of calcium carbonate (calcite) is performed that called MICP [26-30]. MICP has been identified and studied for a broad spectrum of environmental and engineering applications [31,32].

This article aims to evaluate the self-healing and recovery of the main capabilities of pre-cracked cement mortar specimens and the improvement of some mechanical properties using microorganisms. In this regard, the cultured bacteria providing appropriate conditions and nutrients incorporated directly into the mixture. Calcium carbonate precipitation for crack sealing and modification of mechanical properties were investigated in two phases. In the first phase, different amounts of bacterial solution and concentrations of the bacterium were considered. Compressive strength, flexural strength, energy absorption capability, and weight changes of self-healing cement mortar specimens were compared with those of control specimens. Finally, the optimal mix design of self-healing cement mortar was obtained. In the second phase, the recovery of mechanical properties in precracked self-healing specimens with different dimensions of the initial crack was evaluated. Incorporation of microorganisms is expected to heal cracks, regain and improve mechanical and duration properties of cement mortars.

\section{Materials and methods}

\subsection{Bacteria and cultivation conditions}

B. pasteurii (Sporosarcina pasteurii ATCC 11859), which is used in the present study, was purchased from the Persian Type Culture Collection (PTCC - I124). At first, according to the optimum growth condition of the bacteria, an appropriate culture medium was prepared as nutrient brothurea (NBU) included $8 \mathrm{~g} / \mathrm{L}$ nutrient broth and $20 \mathrm{~g} / \mathrm{L}$ urea $(\mathrm{pH}$ 7.5) [33]. All ingredients of the medium were mixed and autoclaved at $121{ }^{\circ} \mathrm{C}$ except the urea that is sensitive to the heat. The urea suspension was sterilized using a 0.45 micrometer filter distinctly. Then sterilized urea suspension was added to other components of the growth medium. In the next step, 3-4 colony of the standard bacterial strain were inoculated to the prepared medium, including urea. Inoculated culture medium was shaken at $30^{\circ} \mathrm{C}$ in $150 \mathrm{rpm}$ for $48 \mathrm{~h}$. Bacterial concentration and growth conditions were evaluated using standard bacterial count methods and also the rate of medium turbidity assay, repeatedly. After gaining the optimum growth of bacterial culture, in intervals, different samples were obtained based on the rate of bacterial growth that was measured using a spectrophotometer (SHIMANDZU- (UV-1800)) for studying the effect of bacterial concentration on the improvement of mechanical properties of cement mortar. OD (Optical Density) of bacterial suspension samples were determined $0.6,1.2$, and 1.7 at a wavelength of $600 \mathrm{~nm}$. Next, the separate cell debris of each obtained sample was collected by centrifugation at $10000 \mathrm{rpm}$ for $15 \mathrm{~min}$, and the process of cell washing was performed with resuspending of bacterial cells in sterile distilled water three times till thoroughly washed [34]. It is essential to mention that during all stages of the test, the growth of bacteria was regularly checked using microscopic analysis [35]. Fig. 1 indicates a microscopic image of the bacterium.

\subsection{Materials of cement mortar}

Washed and graded sand with the water absorption percentage of $1.3 \%$ and a density of $2.76 \mathrm{~g} / \mathrm{cm}^{3}$ were used as fine aggregates. Standard sand grading is in accordance with ASTM C778 [36]. Portland cement type II and potable water were applied. Portland cement type II was selected in this study as one of the most commonly used types of cement. Additional studies are needed to investigate interactions between the bacteria and other types of cement.

\section{Experimental investigations 3.1 Mix designs}

The flexural specimens of cement mortar were prepared according to ASTM C348 [37] for the following aims:

1. Comparison of standard cement mortar with selfhealing cement mortar

2. Preparation of self-healing mortars with optimal bacterial amount and concentration

3. Comparison of improvement rates of self-healing cement mortar specimens

4. Achieving a reliable approach for self-healing

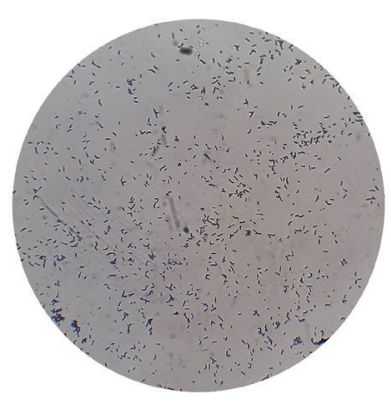

(a)

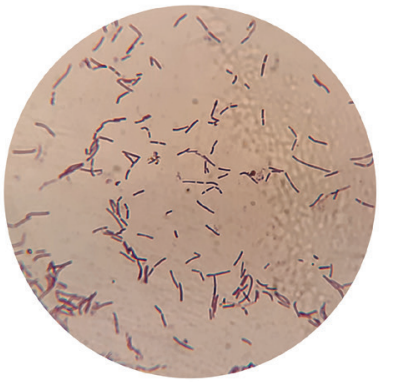

(b)
Fig. 1 Optical microscopic image of the bacterium at magnification a) 100x and b) 1000x 
Details of different specimens and mix designs are presented in Table 1. Cement mortar specimens using Portland cement type II were prepared and mixed according to ASTM C109 [38], with water and bacterial solution to cement ratio of 0.63 . The bacterial solution to cement ratio was 0.145 and 0.03 , and the solution was incorporated immediately after preparation to prevent concentration changes. As will be shown in the results section, the concentration of the bacterial solution with OD of 1.2 is $5.1 \times 10^{7}$ cells $/ \mathrm{ml}$, which is reported to induce maximum compressive strength [33]. ODs of 0.6 and 1.7 are selected to assess the higher and lower concentrations.

The amount of total mixing water was adjusted, such as to produce a flow of $110 \pm 5$ (percentage of the original base diameter). The flow of cement mortars in 25 drops of the flow table was determined according to ASTM C1437 [39]. The procedure for mixing mortars is as follows. First, the mixing water is placed in the mixer. Then the cement is added, and the mixer is started at the slow speed for $30 \mathrm{~s}$. The entire quantity of sand is added over a $30 \mathrm{~s}$ period while mixing. Mixing is continued for another $30 \mathrm{~s}$ at medium speed. The mixer is stopped for $1.5 \mathrm{~min}$ and during the first $15 \mathrm{~s}$ mortar is scraped down into the bath. The bacterial solution is added and mixed for $1 \mathrm{~min}$ at medium speed. The $4 \times 4 \times 16 \mathrm{~cm}$ specimens are molded by evenly distributing layers of mortar in $2 \mathrm{~cm}$ thickness and compacting [37]. The urea and calcium chloride curing environment was used in NC.A to NC.F specimens and was replaced every 7 days to ensure providing fresh nutrients for bacterial activity. Water was used as a curing environment for NC.w specimens. The NC. prefix is used to name the specimens without pre cracking. The difference among NC.A to NC.F specimens is the amount of bacterial solution applied and their OD. Pre-cracked specimens with specific dimensions are named as the number before the letter $\mathrm{D}$ indicates the depth of crack and the number before the letter $\mathrm{W}$ denotes the width of the crack in millimeters.

Aluminum plates with precise dimensions were placed during molding to create initial cracks in the middle of the flexural beam specimens. The specimens were demolded after 24 hours, and self-healing mortars were cured in the culture medium while standard cement mortar specimens were cured in the water.

\subsection{Bacterial concentration and counting test}

One of the common methods to determine cell growth rate is the optical density (OD) measurement of culture medium. The OD shows the amount of absorbed light at a specific wavelength of $600 \mathrm{~nm}$ by the liquid medium in the spectrophotometer. In this method, the optical density has been evaluated by transmitting light with a specific wavelength through the specimen with specified bacterial suspension and measuring the transmitted light percentage, which is called spectrophotometry. In the present research, a UV-Visible Spectrophotometer (UV-1800) of SHIMADZU Company is used.

Table 1 Details of specimens and mix designs

\begin{tabular}{|c|c|c|c|c|c|c|c|c|c|}
\hline \multirow{2}{*}{ Specimen } & & \multirow{2}{*}{$W_{S} / W_{C}$} & \multirow{2}{*}{$\left(W_{W}+W_{B}\right) / W_{C}$} & \multirow{2}{*}{$W_{W} / W_{C}$} & \multirow{2}{*}{$W_{B} / W_{C}$} & \multirow{2}{*}{$O D$} & \multicolumn{3}{|c|}{ Dimensions of pre-crack ${ }^{* *}$} \\
\hline & & & & & & & $W(\mathrm{~mm})$ & $D(\mathrm{~mm})$ & $L(\mathrm{~mm})$ \\
\hline \multirow{7}{*}{ Non-pre-cracked } & NC. A & & & 0.60 & 0.03 & 1.7 & \multirow{7}{*}{-} & \multirow{7}{*}{-} & \multirow{7}{*}{-} \\
\hline & NC. B & & & 0.485 & 0.145 & 1.7 & & & \\
\hline & NC. C & & & 0.60 & 0.03 & 0.6 & & & \\
\hline & NC. D & & & 0.485 & 0.145 & 0.6 & & & \\
\hline & NC. E & & & 0.60 & 0.03 & 1.2 & & & \\
\hline & NC. F & & & 0.485 & 0.145 & 1.2 & & & \\
\hline & NC. w & 2.75 & 0.63 & 0.63 & - & - & & & \\
\hline \multirow{6}{*}{ Pre-cracked* } & $5 \mathrm{D} 0.5 \mathrm{~W}$ & & & \multirow{6}{*}{0.60} & \multirow{6}{*}{0.03} & \multirow{6}{*}{1.2} & & 5 & \multirow{6}{*}{30} \\
\hline & $10 \mathrm{D} 0.5 \mathrm{~W}$ & & & & & & 0.5 & 10 & \\
\hline & $15 \mathrm{D} 0.5 \mathrm{~W}$ & & & & & & & 15 & \\
\hline & $5 \mathrm{D} 1 \mathrm{~W}$ & & & & & & & 5 & \\
\hline & 10D1W & & & & & & 1 & 10 & \\
\hline & 15D1W & & & & & & & 15 & \\
\hline
\end{tabular}

$W_{S}$ : Sand weight, $W_{C}$ : Cement weight, $W_{W}$ : Water weight, $W_{B}:$ Weight of bacterial solution, NC: Non-pre-cracked

* The number before the letter $D$ indicates the depth of crack and the number before the letter $W$ denotes the width of the crack in millimeters.

** $W$ stands for width, $D$ stands for depth, and $L$ stands for length. 
Another method for determining the bacterial concentration is counting bacteria in a diluted media. In this approach, $0.1 \mathrm{ml}$ of bacterial suspension with the concentration of $10^{-8}$ times of the original suspension were incubated at $30^{\circ} \mathrm{C}$ for 24 hours and were counted.

\subsection{Flexural strength test}

Center point flexural test of cement mortar beams was conducted to evaluate flexural strength according to ASTM C348 [37]. Cement mortar specimens with dimensions of $(4 \times 4 \times 16 \mathrm{~cm})$ were loaded with a displacement-based control rate of $0.05 \mathrm{~mm} / \mathrm{min}$ by SANTAM STM-20 universal testing machine. Moreover, the flexural toughness or energy absorption capability was determined by calculating the surface under the mid-span load-deflection curve up to the failure point. Initial cracks were created with specified dimensions according to Table 1 in the middle of the specimens and perpendicular in the transverse direction. Fig. 2 indicates the details and location of the pre-crack, and the loading set up of the center point flexural test.

\subsection{Compressive strength test}

Portions of prisms broken in flexure were used to determine the compressive strength of cement mortars according to ASTM C349 [40] under a loading rate of $1.5 \mathrm{kN} / \mathrm{sec}$. The 7 and 28-day specimens were tested to compare the growth of bacteria in different ages. Fig. 3 shows a cement mortar specimen after the compression test loading.

\subsection{Measurement of weight changes}

The specimens after demolding were weighed with saturated surface dry conditions on the first day and were cured until the defined 7 or 28-day ages and after removing from the curing media, were weighed again with saturated surface dry conditions. Then the percentage of weight changes was calculated in the defined age.

\section{Results and discussion}

In the present research, the compressive and flexural strength, energy absorption capability, weight changes, as well as crack healing in the cement mortar specimens containing microorganisms were evaluated and compared to control specimens of standard cement mortars.

\subsection{Results of non-pre-cracked specimens (phase one)}

Some mechanical properties of standard cement mortar specimens were compared with self-healing cement mortar specimens, without pre-cracks, containing different amounts and concentrations of the bacterial solution to obtain an optimal mix design.

\subsubsection{Bacterial concentration test results}

The bacteria cells of prepared suspension with an optical density (the amount of absorbed light by the liquid medium) of 1.2 were counted in a diluted suspension. The counting of the suspension with a concentration of $10^{-8}$ times of the original suspension showed 51 cells in $100 \mathrm{ml}$. As a result, the concentration of the original solution with OD of 1.2 was $5.1 \times 10^{7}$ cells $/ \mathrm{ml}$.

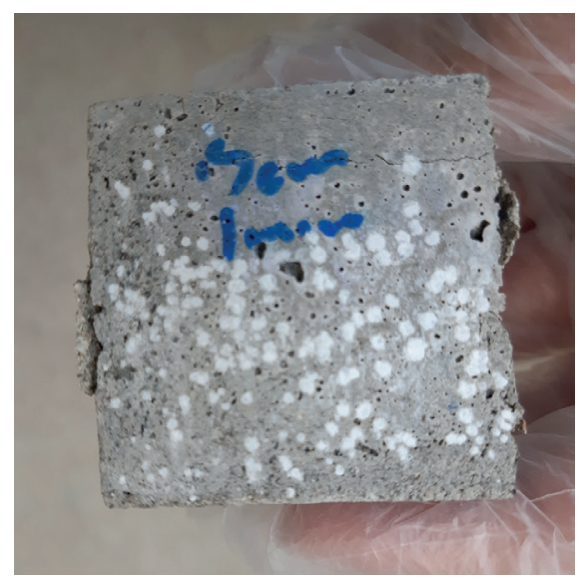

Fig. 3 A cement mortar specimen after the compression test loading

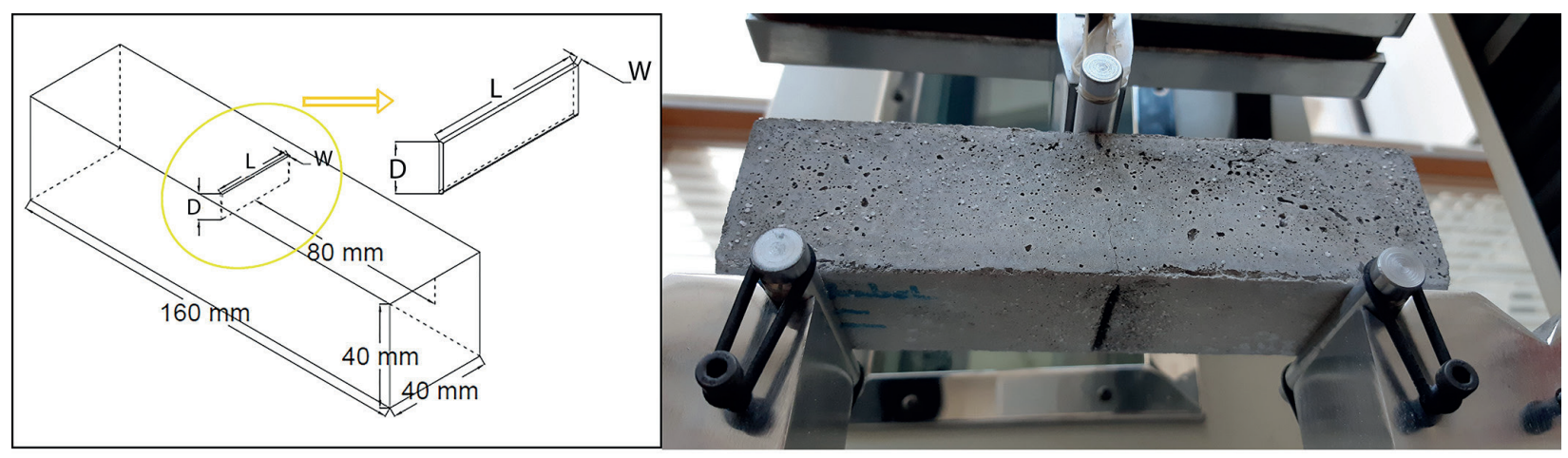

Fig. 2 a) Details and location of the pre-crack, b) A specimen under center point flexural loads 


\subsubsection{Compressive strength test results}

The results of the compressive strength tests at 7 and 28 days are shown in Table 2, that each data is the average of the results of 3 specimens. The effect of microorganisms, regardless of bacterial concentrations and amounts, on improving compressive strength up to 28 days is obvious, and the effect on increasing 7-day compressive strength is noticeable. The NC.E mix design showed the highest compressive strength at 7 days with $24.8 \mathrm{MPa}$, which means an increase of $78 \%$ compared to the control specimen. Also, at 28 days, this mix design had the highest compressive strength of $28.3 \mathrm{MPa}$, which is equivalent to a $45 \%$ increase compared to NC.w control mix design. The compressive strength values of the specimens are compared in Fig. 4.

Improvement of compressive strength of specimens compared to the control specimen (NC.w) at 7 days was more than that at 28 days, which can be attributed to better performance and bacterial activity at early ages. Precipitation of calcium carbonate on the cell surface and in the cement mortar matrix continues during the cell growth while required nutrients and oxygen for bacterial cells are available. Calcite precipitation leads to the reduction of porosity and permeability of the cement mortar, which hinders the flow of nutrients through the pores. Eventually, the cells either die or turn into endospores.

Table 2 Compressive strength of specimens

\begin{tabular}{lccccc}
\hline \multirow{2}{*}{ Specimen } & \multicolumn{5}{c}{ Compressive strength (MPa) } \\
& 7-day & S/C* (\%) & 28-day & S/C* (\%) & 28-day/7-day (\%) \\
\hline NC. A & 16.7 & 119 & 21.6 & 110 & 129 \\
NC. B & 17.3 & 124 & 20.0 & 102 & 116 \\
NC. C & 17.2 & 123 & 19.7 & 101 & 115 \\
NC. D & 18.3 & 131 & 21.8 & 111 & 119 \\
NC. E & 24.8 & 178 & 28.3 & 145 & 114 \\
NC. F & 16.6 & 119 & 20.9 & 107 & 126 \\
NC. w & 14.0 & 100 & 19.6 & 100 & 140 \\
\hline
\end{tabular}

*Self-healing specimen / Control specimen (\%)

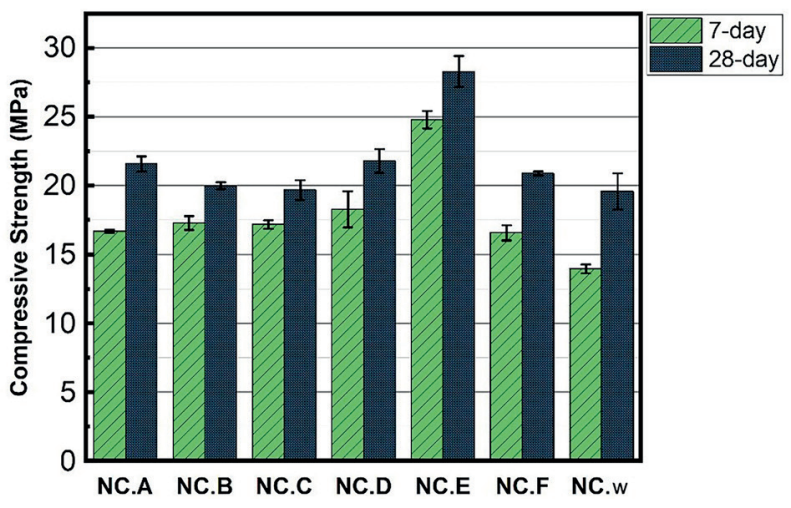

Fig. 4 Compressive strength of 7 and 28-day specimens
Hence the further improvement rate of compressive strengths at early ages may be explained. Similar observations are reported in the literature [12, 33]. Finally, results of the compressive strength of 7 and 28-day cement mortar specimens with OD of 1.2 and the lowest amount of bacterial solution $\left(0.03 W_{B} / W_{C}\right)$ showed the most improvement compared to the mix designs containing microorganism with other bacterial concentrations. Achal et al. [33] reported maximum compressive strength obtained by a bacterial concentration of $5 \times 10^{7}$ cells $/ \mathrm{ml}$ as well.

\subsubsection{Flexural strength test results}

The mid-span load-deflection curves under center point flexural loads for 7 and 28-day cement mortar specimens without pre-cracking are shown in Figs. 5 and 6 in order to compare the flexural strength and energy absorption of the specimens. In addition, the average results of 3 specimens for flexural strength and energy absorption capability are presented in Table 3 and Figs. 7 and 8. All specimens containing microorganisms disclosed enhanced flexural strength and toughness compared to control ones. Flexural strengths of all self-healing cement mortar specimens, similar to compressive strengths, saw accelerated improvement rates at early ages, which may also be attributed to the pores being plugged at older ages, as discussed in the previous section.

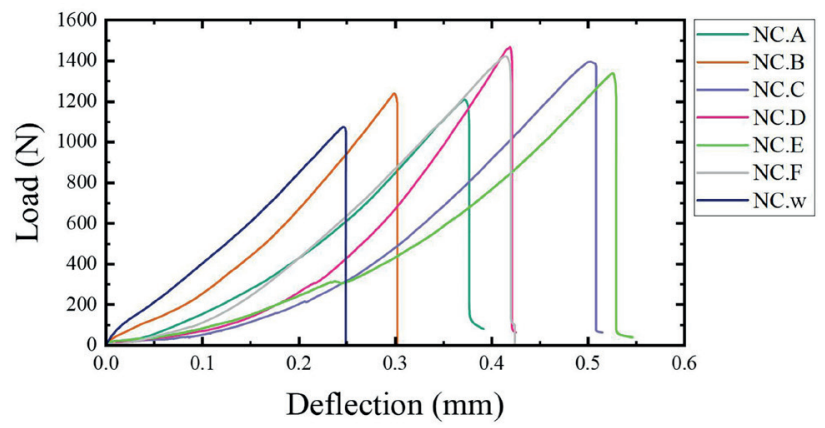

Fig. 5 Mid-span load-deflection curves for non-pre-cracked specimens under center point flexural loads after 7 days of curing

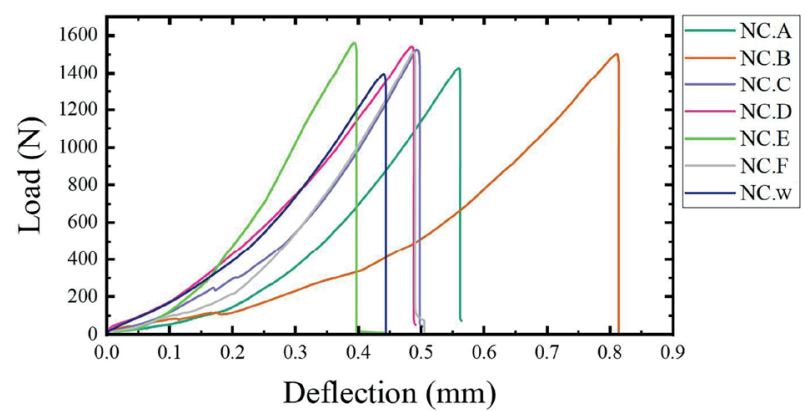

Fig. 6 Mid-span load-deflection curves for non-pre-cracked specimens under center point flexural loads after 28 days of curing 
Table 3 Flexural strength and energy absorption capability of non-pre-cracked specimens

\begin{tabular}{lcccccccc}
\hline \multirow{2}{*}{ Specimen } & \multicolumn{3}{c}{ Flexural strength (MPa) } & \multicolumn{5}{c}{ Energy absorption capability (N.mm) } \\
& 7-day & S/C* $(\%)$ & 28-day & S/C* $(\%)$ & 7-day & S/C* (\%) & 28 -day & S/C* (\%) \\
\hline NC. A & 3.3 & 110 & 3.9 & 104 & 197.6 & 147 & 219.4 & 102 \\
NC. B & 3.4 & 115 & 4.1 & 109 & 194.2 & 144 & 308.3 & 143 \\
NC. C & 3.9 & 129 & 4.3 & 114 & 247 & 183 & 269.9 & 125 \\
NC. D & 4.1 & 138 & 4.3 & 113 & 248.5 & 184 & 280.1 & 130 \\
NC. E & 3.7 & 124 & 4.4 & 118 & 202.1 & 150 & 243.1 & 113 \\
NC. F & 4.0 & 133 & 4.2 & 112 & 271 & 201 & 232 & 108 \\
NC. w & 3.0 & 100 & 3.8 & 100 & 134.8 & 100 & 215.6 & 100 \\
\hline
\end{tabular}

*Self-healing specimen / Control specimen (\%)

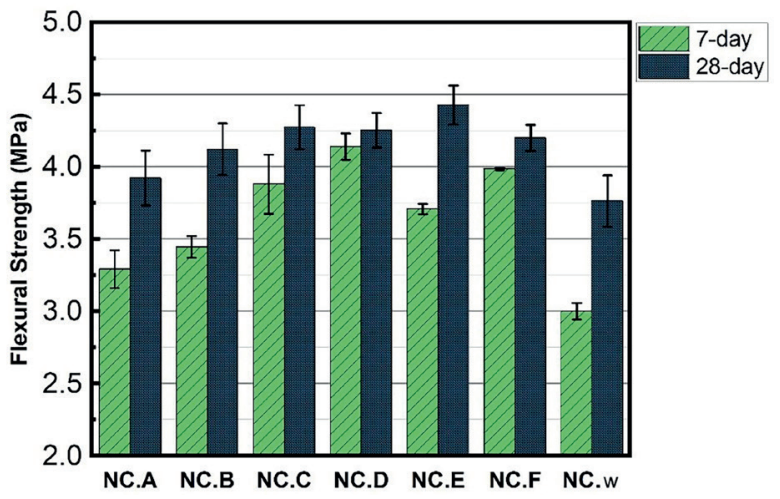

Fig. 7 Flexural strength of non-pre-cracked specimens after 7 and 28 days of curing

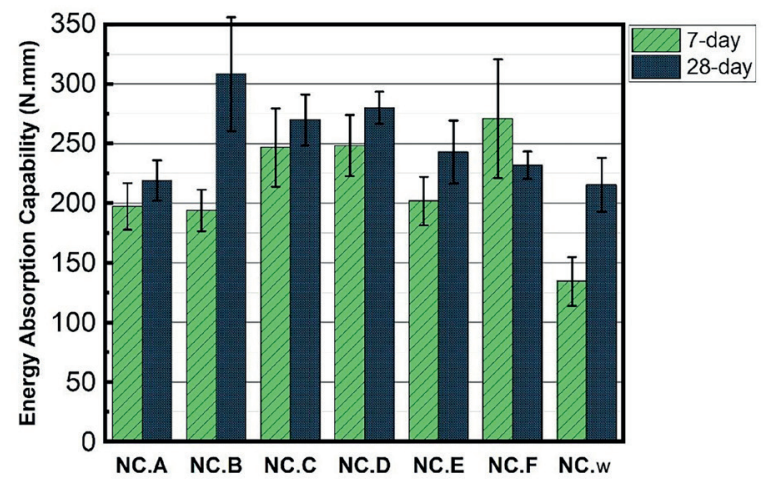

Fig. 8 Energy absorption capability of non-pre-cracked specimens after 7 and 28 days of curing

The most considerable improvement of 7-day flexural strength belonged to the NC.D, NC.F, NC.C, and NC.E specimens, respectively. In all mix designs with constant bacterial concentration, the one containing more amount of bacterial solution had a higher 7-day flexural strength. However, this trend is not seen in the majority of 28-day specimens, which indicates that higher amounts of bacterial solution are not efficient at older ages. According to Fig. 6, in 28-day non-pre-cracked cement mortar specimens, the flexural strength of NC.E, NC.C, NC.D, and NC.F specimens was higher, respectively. This indicates that the NC.E mix design with a 28-day flexural strength of
4.43 MPa revealed the maximum improvement. The energy absorption capability of NC.E specimen was 243.1 N.mm, which was increased $13 \%$ in comparison with the control specimen. However, the results of absorbed energy for the non-pre-cracked specimens presented in Fig. 8 reveal a relatively brittle performance for NC.E specimens.

The results disclosed that NC.E mix designs with the bacterial concentration of $5.1 \times 10^{7}$ cells $/ \mathrm{ml}$ at OD of 1.2 and bacterial solution amount of 0.03 times of cement weight obtained significant strength in the long run compared to standard cement mortars, which not only triggered healing of cracks but also enhanced 28-day flexural and compressive strengths by $17 \%$ and $45 \%$, respectively. This is why NC.E mix designs were selected to pursue research on pre-cracked specimens and to evaluate the recovery of their main mechanical properties.

\subsection{Results of pre-cracked specimens (phase two) 4.2.1 Flexural strength test results}

The mid-span load-deflection curves under center point flexural loads of the 7-day pre-cracked specimens in Fig. 9 shows that the flexural strength from the highest to the lowest, respectively, are related to the NC.w, 5D $0.5 \mathrm{~W}, 10 \mathrm{D} 0.5 \mathrm{~W}$, $5 \mathrm{D} 1 \mathrm{~W}, 15 \mathrm{D} 0.5 \mathrm{~W}, 10 \mathrm{D} 1 \mathrm{~W}$, and $15 \mathrm{D} 1 \mathrm{~W}$ specimens. This trend is partly the same for 28-day flexural strength as NC.w, $5 \mathrm{D} 0.5 \mathrm{~W}, 10 \mathrm{D} 0.5 \mathrm{~W}, 5 \mathrm{D} 1 \mathrm{~W}, 10 \mathrm{D} 1 \mathrm{~W}, 15 \mathrm{D} 0.5 \mathrm{~W}$, and $15 \mathrm{D} 1 \mathrm{~W}$ specimens, which can be seen in Fig. 10. In all of these mix designs, which bacterial solution amount and concentration were kept constant, $5 \mathrm{D} 0.5 \mathrm{~W}$ specimens with a pre-crack of $5 \mathrm{~mm}$ depth and $0.5 \mathrm{~mm}$ width regained most of the 7 and 28 -day flexural strengths with $100 \%$ and $87 \%$ of those of non-pre-cracked NC.w specimen, respectively. Energy absorption and flexural strength results of pre-cracked specimens are presented in Table 4 and are compared in Figs. 11 and 12. As expected, the flexural strength and energy absorption capability of the specimens decreased by increasing the depth and width of the pre-cracks. 
Table 4 Flexural strength and energy absorption capability of control and pre-cracked specimens

\begin{tabular}{|c|c|c|c|c|c|c|c|c|}
\hline \multirow{2}{*}{ Specimen } & \multicolumn{4}{|c|}{ Flexural strength $(\mathrm{MPa})$} & \multicolumn{4}{|c|}{ Energy absorption capability (N.mm) } \\
\hline & 7-day & $\mathrm{S} / \mathrm{C}^{*}(\%)$ & 28-day & $\mathrm{S} / \mathrm{C}^{*}(\%)$ & 7 -day & $\mathrm{S} / \mathrm{C} *(\%)$ & 28 -day & $\mathrm{S} / \mathrm{C} *(\%)$ \\
\hline NC. w & 3.0 & 100 & 3.8 & 100 & 134.8 & 100 & 215.6 & 100 \\
\hline $5 \mathrm{D} 0.5 \mathrm{~W}$ & 3.0 & 100 & 3.3 & 87 & 110.6 & 82 & 135.7 & 63 \\
\hline $10 \mathrm{D} 0.5 \mathrm{~W}$ & 2.5 & 83 & 2.8 & 74 & 102.9 & 76 & 127.4 & 59 \\
\hline $15 \mathrm{D} 0.5 \mathrm{~W}$ & 1.6 & 53 & 1.8 & 47 & 62.6 & 46 & 76.5 & 35 \\
\hline $5 \mathrm{D} 1 \mathrm{~W}$ & 2.4 & 80 & 2.8 & 74 & 81.2 & 60 & 108 & 50 \\
\hline 10D1W & 1.3 & 43 & 2.4 & 63 & 27.6 & 20 & 87.4 & 41 \\
\hline 15D1W & 1.1 & 37 & 1.6 & 42 & 21.3 & 16 & 83.7 & 39 \\
\hline
\end{tabular}

*Self-healing specimen / Control specimen (\%)

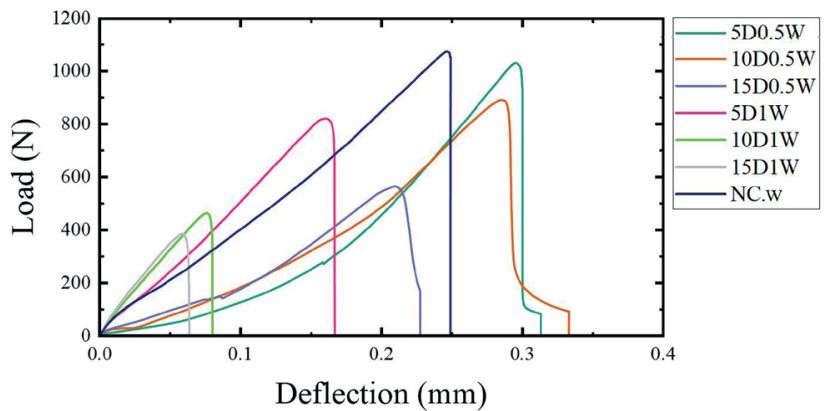

Fig. 9 Mid-span load-deflection curves for pre-cracked and control specimens under center point flexural loads after 7 days of curing

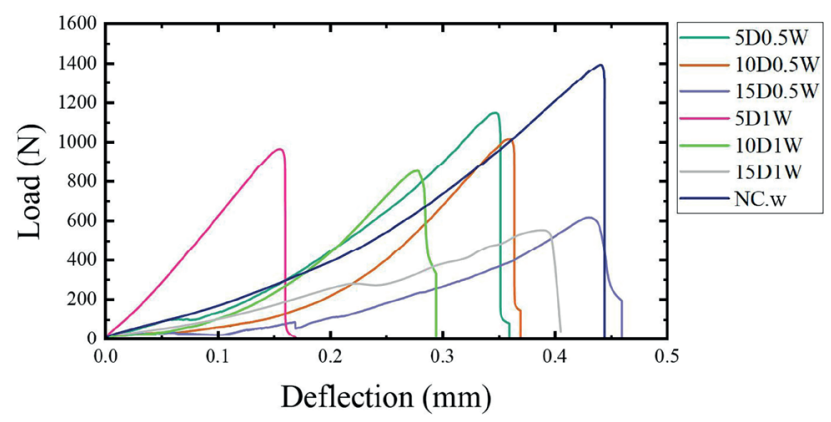

Fig. 10 Mid-span load-deflection curves for pre-cracked and control specimens under center point flexural loads after 28 days of curing

Flexural strength of self-healing cement mortar specimens with different dimensions of pre-cracks evaluated and compared with those of non-pre-cracked standard cement mortar specimens. The goal was to assess the efficiency of the incorporation of the optimal amount and concentration of bacterial solution to seal the cracks and recover the strength. In the specimens with a precrack of $0.5 \mathrm{~mm}$ width, the rate of obtaining strength was accelerated during the first 7 days in comparison with 28-day results, which can be attributed to the more efficient bacterial activity of self-healing cement mortars at early ages, similar to the non-pre-cracked specimens. However, in most of the specimens with a pre-crack of $1.0 \mathrm{~mm}$ width, calcite precipitation in 28 days healed the

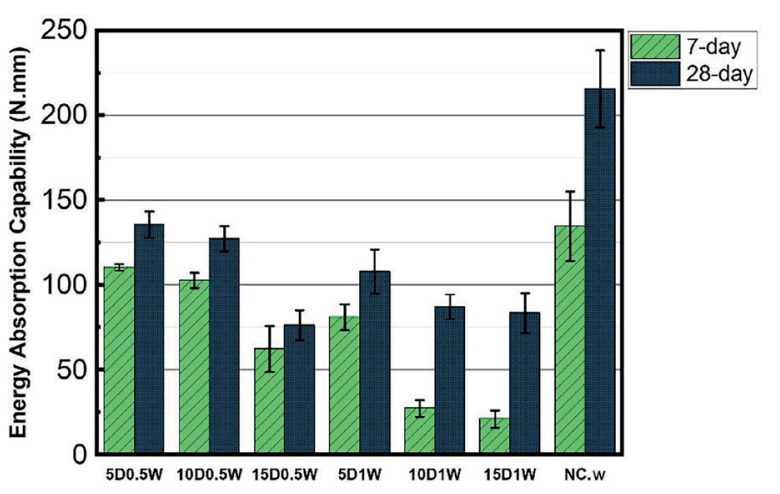

Fig. 11 Energy absorption capability of pre-cracked and control specimens after 7 and 28 days of curing

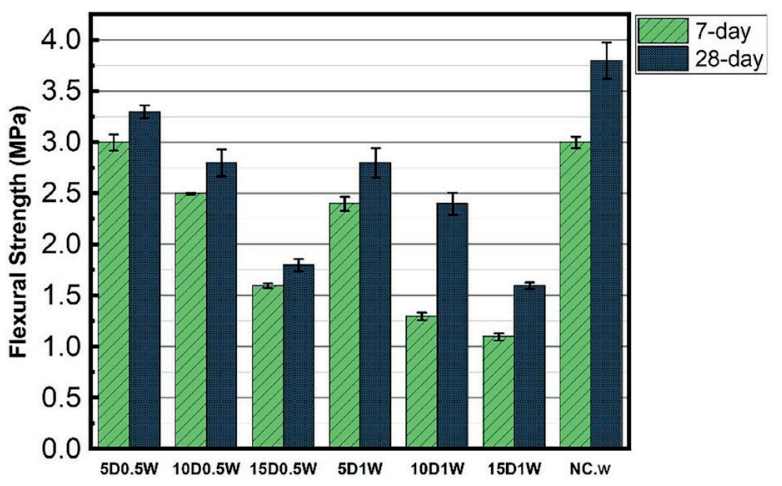

Fig. 12 Flexural strength of pre-cracked and control specimens after 7 and 28 days of curing

cracks more efficient than early ages, which means that hindrance of the nutrient flow due to plugging of the pores does not occur in the wider cracks.

\subsubsection{Experimental flexural strengths compared to their theoretical values}

According to the dimensions of the pre-cracks of the specimens, theoretical flexural strengths were calculated based on the reduced cross-sections and compared with results obtained from the center point flexural test. In this way, dimensions of cracks in the specimens containing 
microorganisms that have the capability to be recovered and healed can be specified. Comparison of the experimental and theoretical flexural strengths of pre-cracked self-healing specimens with non-pre-cracked standard cement mortar specimen are shown in Table 5. As shown in Table 5, 28-day experimental flexural strengths of all pre-cracked specimens are greater than their expected theoretical values, which means that self-healing occurred. Although complete recovery did not take place, in pre-cracks with smaller dimensions, higher recovery degrees are achieved. Apparently, wider cracks require more than 28 days to be filled with calcite precipitation due to bacterial activity in the direct addition of bacteria, as can be seen from comparison between pre-cracked specimens with $0.5 \mathrm{~mm}$ and $1.0 \mathrm{~mm}$ width of the cracks. Moreover, comparison among pre-cracked specimens with $5 \mathrm{~mm}$ and $10 \mathrm{~mm}$ and $15 \mathrm{~mm}$ depth of the cracks reveals that deeper the cracks get, lower the healing amount becomes in 28 days. So far, healing of the maximum crack width of $0.97 \mathrm{~mm}$ is reported [1].

According to measured 7 and 28-day weight changes given in Table 6 and Figs. 13 and 14, the weight increase of self-healing specimens was more considerable compared to the control specimen (NC.w). Among all specimens, NC.E specimen experienced a maximum 7-day weight change. Weight changes in 28 days indicate that NC.A and NC.B specimens, with the highest bacterial concentration, gained more weight. Bacterial spores were able to grow in contact with moisture and nutrients of the curing environment and produce calcium carbonate. The weight increase of specimens can be attributed to the precipitation due to bacterial activity, which leads to crack healing and recovery of main mechanical and duration properties. Although bacterial cells receive nutrients at early ages, bacteria may not grow properly due to their completely new environment.

Table 5 Experimental and theoretical flexural strengths of pre-cracked

\begin{tabular}{lccccc}
\multicolumn{5}{c}{ specimens } \\
\hline Specimen & Experimental flexural strength $(\mathrm{MPa})$ & $\begin{array}{c}\text { Theoretical } \\
\text { flexural } \\
\text { strength } \\
\text { S/C* }(\%)\end{array}$ \\
\hline NC. w & 3.0 & 100 & 3.8 & 100 & 100 \\
5D0.5W & 3.0 & 100 & 3.3 & 87 & 76 \\
10D0.5W & 2.5 & 83 & 2.8 & 74 & 56 \\
15D0.5W & 1.6 & 53 & 1.8 & 47 & 39 \\
5D1W & 2.4 & 80 & 2.8 & 74 & 76 \\
10D1W & 1.3 & 43 & 2.4 & 63 & 56 \\
15D1W & 1.1 & 37 & 1.6 & 42 & 39 \\
\hline
\end{tabular}

*Self-healing specimen / Control specimen (\%)
Table 6 Weight changes of specimens

\begin{tabular}{lcc}
\hline Specimen & \multicolumn{2}{c}{$\Delta W(\%)$} \\
\hline NC. A & 7-day & 28 -day \\
NC. B & 2.26 & 3.09 \\
NC. C & 2.01 & 3.94 \\
NC. D & 1.59 & 2.32 \\
NC. E & 1.71 & 2.52 \\
NC. F & 3.17 & 2.37 \\
NC. $W$ & 1.69 & 1.59 \\
5D0.5W & 1.14 & 1.09 \\
10D0.5W & 1.47 & 1.61 \\
15D0.5W & 1.46 & 1.54 \\
5D1W & 1.53 & 1.7 \\
10D1W & 1.3 & 1.7 \\
15D1W & 1.28 & 1.57 \\
\hline
\end{tabular}

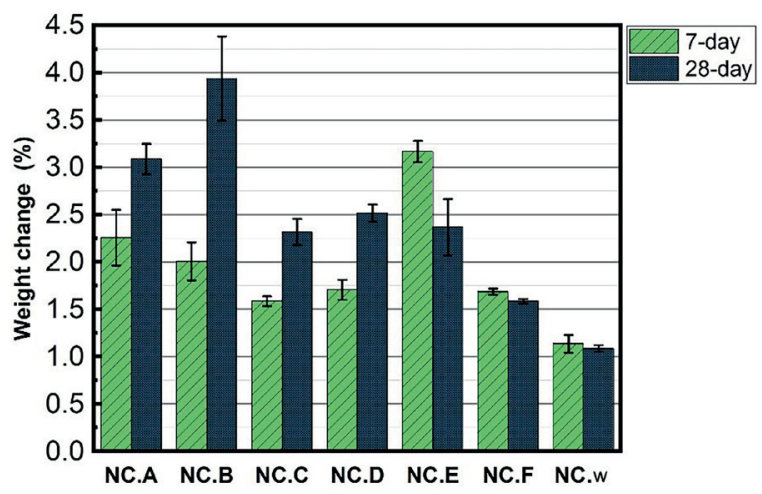

Fig. 13 Weight changes of non-pre-cracked specimens after 7 and 28 days of curing

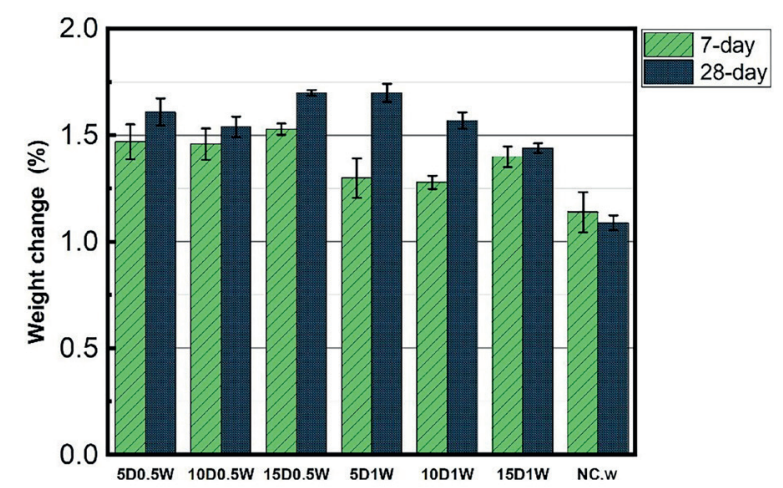

Fig. 14 Weight changes of pre-cracked and control specimens after 7 and 28 days of curing

\subsubsection{Observations of precipitation and crack healings}

Visual observations showed that filling of crack was significant in 5D0.5W, 10D0.5W, 15D0.5W, and 5D1W specimens, and small amounts of precipitation were found in the cracks with greater dimensions (Fig. 15). In self-healing specimens, after 28 days of curing, not only were the cracks 
wholly filled but also the surface of the specimens was partially covered by white precipitations. Even precipitations penetrated into the pores of the cracks (Fig. 16). In specimens containing microorganisms, non-pre-cracked ones exhibited improvement of mechanical properties, while precracked ones partly recovered the main capabilities depending on the crack dimension. Cracks with a width of $0.5 \mathrm{~mm}$ healed up to a depth of $15 \mathrm{~mm}$ and cracks with a width of 1 $\mathrm{mm}$ healed up to a depth of $5 \mathrm{~mm}$. Although precipitation observed in the cracks with larger dimensions, recovery of mechanical properties was not noticeable.

The calcium carbonate precipitation due to bacterial activity fills the crack, and its protective effect against steel corrosion will be investigated in future studies.

The visual observation of crack filling verified the obtained mechanical strengths. The quantitive methods will be employed in the subsequent durability studies.

\section{Conclusions}

The present study showed the effect of calcium carbonate precipitation due to bacterial activity on both the improvement of mechanical properties and the healing of cracks in cement mortars. Incorporation of microorganisms, under

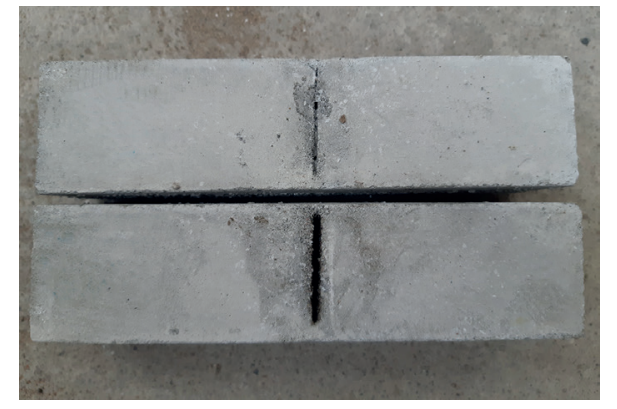

Fig. 15 Filling of the cracks with widths of 0.5 and $1.0 \mathrm{~mm}$ after 28 days of curing

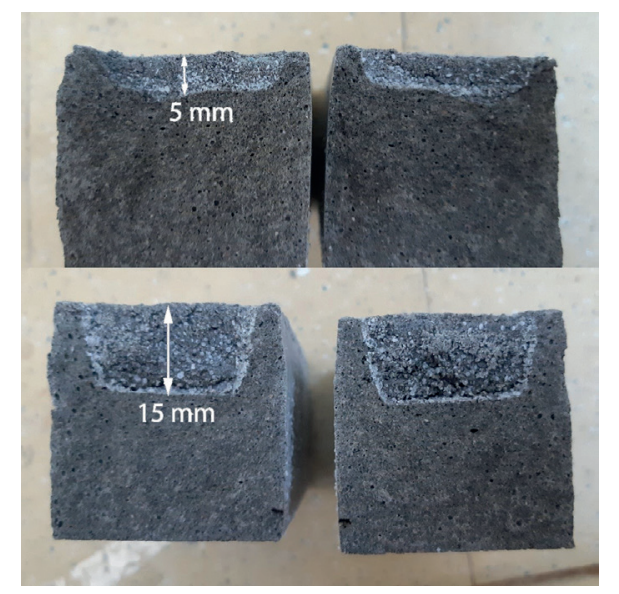

Fig. 16 Cross-section of pre-cracked specimens after flexural test controlled conditions with optimal amount and concentration, in self-healing cement mortars not only resulted in sealing of the cracks and recovery of main properties in pre-cracked specimens but also enhanced mechanical properties of non-pre-cracked specimens.

In non-pre-cracked specimens, adding 0.03 times of cement weight bacterial suspension with a concentration of $5.1 \times 10^{7}$ cells $/ \mathrm{ml}$ (optical density of 1.2 ) resulted in increasing compressive and flexural strengths. The NC.E mix design revealed a $78 \%$ improvement of compressive strength at 7 days and a $45 \%$ improvement at 28 days compared to the control mix design NC.w. According to the center point flexural test, the NC.E specimens exhibited the highest 28-day flexural strength by an $18 \%$ increase compared to control specimens. Nevertheless, their flexural toughness by a $13 \%$ increase was not at the highest level. The increase of flexural strength and toughness for NC.E specimens compared to the control specimens at 7 days were $24 \%$ and $50 \%$, respectively. Although the curing media containing nutrients for bacterial activity was replaced every 7 days, healing performance at 7 days was more efficient compared to 28 days in terms of compressive and flexural strengths.

In pre-cracked specimens, flexural strength and energy absorption capability decreased by increasing the depth and width of the cracks. 5D $0.5 \mathrm{~W}$ specimens with 5 $\mathrm{mm}$ depth and $0.5 \mathrm{~mm}$ width of pre-crack had the best self-healing capability with the 7-day and 28-day flexural strengths of $100 \%$ and $87 \%$ of non-pre-cracked NC.w control specimens. The healing rates at 7 days were more than those at 28 days, as similarly observed in non-pre-cracked specimens. Hindering the nutrient and oxygen flow due to the plugging of the pores may decrease the healing rate at older ages. Specimens with other dimensions of pre-crack partly regained flexural strengths depending on the size of the initial crack.

Healing of the cracks stems from the calcite precipitation due to the activity of microorganisms and the growth of bacteria in moist media containing nutrients, which is accompanied by increased weights of specimens. The weight increase of self-healing cement mortar specimens was more than those of control specimens.

In pre-cracked specimens with cracks of $0.5 \mathrm{~mm}$ width, healing took place up to a depth of $15 \mathrm{~mm}$, while in those with cracks of $1.0 \mathrm{~mm}$ width, healing occurred up to a depth of $5 \mathrm{~mm}$. In specimens with larger crack dimensions, precipitation observed, however, regaining mechanical properties was not noticeable. 


\section{References}

[1] Muhammad, N. Z., Shafaghat, A., Keyvanfar, A., Majid, M. Z. A., Ghoshal, S. K., ..., McCaffer, R. "Tests and methods of evaluating the self-healing efficiency of concrete: A review", Construction and Building Materials, 112, pp. 1123-1132, 2016. https://doi.org/10.1016/j.conbuildmat.2016.03.017

[2] Wu, M., Johannesson, B., Geiker, M. "A review: Self-healing in cementitious materials and engineered cementitious composite as a self-healing material", Construction and Building Materials, 28(1), pp. 571-583, 2012.

https://doi.org/10.1016/j.conbuildmat.2011.08.086

[3] Yang, Y., Yang, E.-H., Li, V. C. "Autogenous healing of engineered cementitious composites at early age", Cement and Concrete Research, 41(2), pp. 176-183, 2011.

https://doi.org/10.1016/j.cemconres.2010.11.002

[4] Sidiq, A., Gravina, R., Giustozzi, F. "Is concrete healing really efficient? A review", Construction and Building Materials, 205, pp. 257-273, 2019.

https://doi.org/10.1016/j.conbuildmat.2019.02.002

[5] Li, W., Zhu, X., Zhao, N., Jiang, Z. "Preparation and Properties of Melamine Urea-Formaldehyde Microcapsules for Self-Healing of Cementitious Materials", Materials, 9(3), Article number: 152, 2016.

https://doi.org/10.3390/ma9030152

[6] Mostavi, E., Asadi, S., Hassan, M. M., Alansari, M. "Evaluation of Self-Healing Mechanisms in Concrete with Double-Walled Sodium Silicate Microcapsules", Journal of Materials in Civil Engineering, 27(12), Article number: 04015035, 2015.

https://doi.org/10.1061/(asce)mt.1943-5533.0001314

[7] Kanellopoulos, A., Qureshi, T. S., Al-Tabbaa, A. "Glass encapsulated minerals for self-healing in cement based composites", Construction and Building Materials, 98, pp. 780-791, 2015.

https://doi.org/10.1016/j.conbuildmat.2015.08.127

[8] Wang, J. Y., Soens, H., Verstraete, W., De Belie, N. "Self-healing concrete by use of microencapsulated bacterial spores", Cement and Concrete Research, 56, pp. 139-152, 2014.

https://doi.org/10.1016/j.cemconres.2013.11.009

[9] Souradeep, G., Kua, H. W. "Encapsulation technology and techniques in self-healing concrete", Journal of Materials in Civil Engineering, 28(12), Article number: 04016165, 2016. https://doi.org/10.1061/(ASCE)MT.1943-5533.0001687

[10] Zhang, J., Liu, Y., Feng, T., Zhou, M., Zhao, L., Zhou, A., Li, Z. "Immobilizing bacteria in expanded perlite for the crack self-healing in concrete", Construction and Building Materials, 148, pp. 610-617, 2017.

https://doi.org/10.1016/j.conbuildmat.2017.05.021

[11] Seifan, M., Sarmah, A. K., Samani, A. K., Ebrahiminezhad, A., Ghasemi, Y., Berenjian, A. "Mechanical properties of bio self-healing concrete containing immobilized bacteria with iron oxide nanoparticles", Applied Microbiology and Biotechnology, 102(10), pp. 4489-4498, 2018.

https://doi.org/10.1007/s00253-018-8913-9

[12] Vijay, K., Murmu, M., Deo, S. V. "Bacteria based self healing concrete - A review", Construction and Building Materials, 152, pp. 1008-1014, 2017

https://doi.org/10.1016/j.conbuildmat.2017.07.040
[13] Lee, Y. S., Park, W. "Current challenges and future directions for bacterial self-healing concrete", Applied Microbiology and Biotechnology, 102(7), pp. 3059-3070, 2018.

https://doi.org/10.1007/s00253-018-8830-y

[14] Williams, S. L., Kirisits, M. J., Ferron, R. D. "Influence of concrete-related environmental stressors on biomineralizing bacteria used in self-healing concrete", Construction and Building Materials, 139, pp. 611-618, 2017. https://doi.org/10.1016/j.conbuildmat.2016.09.155

[15] Wang, J., Van Tittelboom, K., De Belie, N., Verstraete, W. "Use of silica gel or polyurethane immobilized bacteria for self-healing concrete", Construction and Building Materials, 26(1), pp. 532540, 2012. https://doi.org/10.1016/j.conbuildmat.2011.06.054

[16] Xu, J., Wang, X. "Self-healing of concrete cracks by use of bacteria-containing low alkali cementitious material", Construction and Building Materials, 167, pp. 1-14, 2018. https://doi.org/10.1016/j.conbuildmat.2018.02.020

[17] Lucas, S. S., Moxham, C., Tziviloglou, E., Jonkers, H. "Study of self-healing properties in concrete with bacteria encapsulated in expanded clay", Science and Technology of Materials, 30, pp. 93-98, 2018. https://doi.org/10.1016/j.stmat.2018.11.006

[18] Alazhari, M., Sharma, T., Heath, A., Cooper, R., Paine, K. "Application of expanded perlite encapsulated bacteria and growth media for self-healing concrete", Construction and Building Materials, 160, pp. 610-619, 2018.

https://doi.org/10.1016/j.conbuildmat.2017.11.086

[19] Nain, N., Surabhi, R., Yathish, N. V., Krishnamurthy, V, Deepa, T., Tharannum, S. "Enhancement in strength parameters of concrete by application of Bacillus bacteria", Construction and Building Materials, 202, pp. 904-908, 2019.

https://doi.org/10.1016/j.conbuildmat.2019.01.059

[20] Khaliq, W., Ehsan, M. B. "Crack healing in concrete using various bio influenced self-healing techniques", Construction and Building Materials, 102, pp. 349-357, 2016. https://doi.org/10.1016/j.conbuildmat.2015.11.006

[21] Stuckrath, C., Serpell, R., Valenzuela, L. M., Lopez, M. "Quantification of chemical and biological calcium carbonate precipitation: Performance of self-healing in reinforced mortar containing chemical admixtures", Cement and Concrete Composites, 50, pp. 10-15, 2014.

https://doi.org/10.1016/j.cemconcomp.2014.02.005

[22] Abo-El-Enein, S. A., Ali, A. H., Talkhan, F. N., Abdel-Gawwad, H. A. "Application of microbial biocementation to improve the physico-mechanical properties of cement mortar", HBRC Journal, 9(1), pp. 36-40, 2013. https://doi.org/10.1016/j.hbrcj.2012.10.004

[23] Abo-El-Enein, S. A., Ali, A. H., Talkhan, F. N., Abdel-Gawwad, H. A. "Utilization of microbial induced calcite precipitation for sand consolidation and mortar crack remediation", HBRC Journal, 8(3), pp. 185-192, 2019. https://doi.org/10.1016/j.hbrcj.2013.02.001 
[24] Dhami, N. K., Reddy, M. S., Mukherjee, A. "Biomineralization of calcium carbonates and their engineered applications: a review", Frontiers in Microbiology, 4, Article number: 314, 2013. https://doi.org/10.3389/fmicb.2013.00314

[25] Phillips, A. J., Gerlach, R., Lauchnor, E., Mitchell, A. C., Cunningham, A. B., Spangler, L. "Engineered applications of ureolytic biomineralization: a review", Biofouling, 29(6), pp. 715-733, 2013.

https://doi.org/10.1080/08927014.2013.796550

[26] Lauchnor, E. G., Schultz, L. N., Bugni, S., Mitchell, A. C., Cunningham, A. B., Gerlach, R. "Bacterially induced calcium carbonate precipitation and strontium coprecipitation in a porous media flow system", Environmental Science \& Technology, 47(3), pp. 1557-1564, 2013.

https://doi.org/10.1021/es304240y

[27] Cuthbert, M. O., Riley, M. S., Handley-Sidhu, S., Renshaw, J. C., Tobler, D. J., Phoenix, V. R., Mackay, R. "Controls on the rate of ureolysis and the morphology of carbonate precipitated by $\mathrm{S}$. Pasteurii biofilms and limits due to bacterial encapsulation", Ecological Engineering, 41, pp. 32-40, 2012. https://doi.org/10.1016/j.ecoleng.2012.01.008

[28] Al Qabany, A., Soga, K., Santamarina, C. "Factors affecting efficiency of microbially induced calcite precipitation", Journal of Geotechnical and Geoenvironmental Engineering, 138(8), pp. 992-1001, 2012. https://doi.org/10.1061/(ASCE)GT.1943-5606.0000666

[29] Stocks-Fischer, S., Galinat, J. K., Bang, S. S. "Microbiological precipitation of $\mathrm{CaCO}_{3}$ ", Soil Biology and Biochemistry, 31(11), pp. 1563-1571, 1999. https://doi.org/10.1016/S0038-0717(99)00082-6

[30] Okwadha, G. D. O., Li, J. "Optimum conditions for microbial carbonate precipitation", Chemosphere, 81(9), pp. 1143-1148, 2010. https://doi.org/10.1016/j.chemosphere.2010.09.066

[31] Chafetz, H. S. "Marine peloids; a product of bacterially induced precipitation of calcite", Journal of Sedimentary Research, 56(6), pp. 812-817, 1986.

https://doi.org/10.1306/212F8A58-2B24-11D7-8648000102C1865D
[32] Morita, R. Y. "Calcite precipitation by marine bacteria", Geomicrobiology Journal, 2(1), pp. 63-82, 1980. https://doi.org/10.1080/01490458009377751

[33] Achal, V., Mukerjee, A., Sudhakara Reddy, M. "Biogenic treatment improves the durability and remediates the cracks of concrete structures", Construction and Building Materials, 48, pp. 1-5, 2013. https://doi.org/10.1016/j.conbuildmat.2013.06.061

[34] Jadhav, U. U., Lahoti, M., Chen, Z., Qiu, J., Cao, B., Yang, E.-H. "Viability of bacterial spores and crack healing in bacteria-containing geopolymer", Construction and Building Materials, 169, pp. 716-723, 2018.

https://doi.org/10.1016/j.conbuildmat.2018.03.039

[35] Bhaskar, S., Anwar Hossain, K. M., Lachemi, M., Wolfaardt, G., Otini Kroukamp, M. "Effect of self-healing on strength and durability of zeolite-immobilized bacterial cementitious mortar composites", Cement and Concrete Composites, 82, pp. 23-33, 2017. https://doi.org/10.1016/j.cemconcomp.2017.05.013

[36] ASTM "ASTM C778-17 Standard Specification for Standard Sand", ASTM International, West Conshohocken, PA, USA, 2017. https://doi.org/10.1520/C0778-17

[37] ASTM "ASTM C348-19, Standard Test Method for Flexural Strength of Hydraulic-Cement Mortars", ASTM International, West Conshohocken, PA, USA, 2019.

https://doi.org/10.1520/C0348-18

[38] ASTM "ASTM C109/C109M-20, Standard Test Method for Compressive Strength of Hydraulic Cement Mortars (Using 2-in. or [50-mm] Cube Specimens)", ASTM International, West Conshohocken, PA, USA, 2020. https://doi.org/10.1520/C0109_C0109M-16A

[39] ASTM "ASTM C1437-15, Standard Test Method for Flow of Hydraulic Cement Mortar", ASTM International, West Conshohocken, PA, USA, 2015. https://doi.org/10.1520/C1437-15

[40] ASTM "ASTM C349-18 Standard Test Method for Compressive Strength of Hydraulic-Cement Mortars (Using Portions of Prisms Broken in Flexure)", ASTM International, West Conshohocken, PA, USA, 2018. https://doi.org/10.1520/C0349-18 